\title{
Manggarai Local Wisdom-Based Curriculum Development Model in Early Childhood Education of Bunda Maria Grazia, Langke Rembong District, Manggarai Regency
}

\author{
Adriani Tamo Ina Talu ${ }^{1}$, Ignasius F. R. Bora ${ }^{2}$, \\ Beata Palmin ${ }^{3}$, and Yasinta $\mathrm{Sidi}^{4}$ \\ \{inatalu@gmail.com¹, peppy_bora78@yahoo.com², bepalmin4@gmail.com³, shyntasidi@gmail.com ${ }^{4}$ \}
}

Sint Paul Ruteng Chatolic University of Indonesia ${ }^{1234}$

\begin{abstract}
Teachers have a strategic role in developing the curriculum. Early Childhood Education of Bunda Maria Grazia in Nekang-Ruteng has developed a curriculum based on Manggarai local wisdom. The research objective was to describe a curriculum development model based on Manggarai local wisdom in Bunda Maria Grazia Early Childhood Education. The research method used here was descriptive qualitative. Data collection techniques using observation, interview and documentation techniques. Test the validity of the data using the triangulation technique. The data obtained were analyzed using Miles \& Huberman's theory which includes data reduction, data display and conclusions. The results showed that the curriculum development model appeared in the development of Planning and Learning Development. In develop the planning, the institution develops themes and sub-themes that embrace cultural elements and in the development of learning, the teacher chooses games and interesting media according to the themes and sub-themes that have been developed.
\end{abstract}

Keywords: Attitude; Curriculum, Local Wisdom, Early Childhood Education

\section{Introduction}

Indonesia has areas with a variety of cultures and regional conditions such as mountains, villages, cities, industries, beaches, rivers and even the sea. Each environment has a community with a different and unique style of life or culture, starting from the way of life, habits, environmental conditions, customs, folk songs to playing tools used as children (Masnipal, 2016: 173). To realize the diversity that presence in Indonesia, an educational service program is needed to bridge this diversity. The form of education services that is currently being discussed intensively and constitutes a formal education service aimed at all groups is schools.

School is a vehicle for the formal education process. Schools are part of the community; therefore, schools must be able to strive for the preservation of the characteristics or uniqueness of the environment or where the school is located. To realize these efforts, schools must present educational programs that can provide insights to students about the characteristics of the environment in their areas, related to natural conditions, social and cultural environments, as well as regional needs (Idi, 2014: 203). Educational programs developed in schools must be adapted to the regional potential, interests and needs of the students. This means that schools 
must develop an educational program that is oriented towards the surrounding environment and regional potential or in short, local content.

Children's education in kindergarten is included in the formal education pathway under the auspices of the Ministry of Education and Culture. All educators have the duty to stimulate children's development. Various ways should be done so that the learning conditions provided in schools is able to stimulate child's development optimally. Efforts that can be made by the teachers in stimulating children's development are to prepare children by continuing and provide learning needs to develop religious and moral values, physical and motor skills, cognitive, language, socio-emotional and children's arts.

Because of the unique characteristics of children, active learners in learning, egocentric and considered as the most potential period for learning, learning in early childhood institution must involve children directly and introduce real life for them in learning. This is because by learning, children will be helped in knowing themselves, knowing whom the child lives with and getting to know their live environment so that that environment could affect the learning process that the child will receive. As well as with the cultural environment, especially for the local culture where the child lives, will also play an important role in shaping the character of the child in receiving learning about themselves and their world.

This was emphasized by Vygotsky (Yusuf \& Rahmat, 2020: 62) who stated that the contribution of culture, social interaction and history in the mental/behavioral development of children is very influential. Learning-based on culture and social interaction refers to sociohistorical-cultural development aspects that will greatly impact children's perceptions, memories and ways of thinking. Culture teaches children about cultural values so that they could understand their cultural environment. Local wisdom refers to various cultural properties that grow and develop in a society that is known, trusted and recognized as important elements for strengthening social cohesion among the community members. Local wisdom becomes the capital for the formation of noble characters (Siahaan, 2018: 649). And the value of that local wisdom is implemented in local content teaching and learning in schools.

The Permendikbud No. 146/2014 explains that the developed curriculum must take into account the -cultural characteristics of the local community and support the preservation of cultural diversity. The curriculum needs to contain a variety of potential needs, challenges, and characteristics of the local environment to produce children who know, appreciate and love that local culture. The development of curriculum content based on Manggaraian local wisdom is the most important thing because in this way children can get to know more about their local culture or what is the characteristics of the region specifically. The development of curriculum content based on Manggaraian local wisdom would indirectly instill the children starting from an early age to make them able love and live their own local culture. For sure, the people who possess an important role in developing the PAUD curriculum specifically local wisdom-based curriculum content are the teachers.

Basically, teachers must be able to develop the PAUD curriculum based on the conditions and situations of the school environment, because children will get a ton of meaningful learning experiences from their environment. The curriculum enhances the basic foundation of a school to carry out the learning processes and could be the references for schools to achieve educational goals. The process of developing curriculum based on local content is not a process that can take place spontaneously because it must be adapted to the situation or conditions of the area where the school is located. Ability, hard work and creativity are the supporting factors needed to encourage the realization of optimal curriculum development results.

Local culture-based learning for early childhood education according to Sugiyanti (2012: 8 ) is a learning program that provides educational stimulation to assist children's physical and 
spiritual growth and development by emphasizing understanding and appreciation of the way of life, customs, habits, traditions, arts, thoughts, a value system, a way of working that is typical to a particular community or ethnic group.

The development of cultural values in PAUD particularly aims to install in the children's life from an early age, compassion and love for their own local culture. The result that will be achieved is that the children will progress and develop into a person who is aware of the importance of the culture. The education in PAUD is design to develop early childhood abilities as heirs to the Indonesian nation's culture who are creative and care about the nation's problems.

\section{Methodology}

This type of research used here is descriptive research. According to Arikunto (2010: 264) descriptive research is a study that aims to describe or explain something, for example circumstances, conditions, situations, events, activities and others. What this research intends to describe is the Manggaraian local wisdom-based curriculum development model in PAUD Bunda Maria Grazia, Nekang, Ruteng. Data collection techniques using observation, interview and documentation techniques. Test the validity of the data using the triangulation technique. Sugiyono (2015: 330) states that triangulation is a data collection technique that combines various data collection techniques and existing data sources. Technique triangulation means that researchers use different data collection techniques to obtain data from the same source. Researchers used participatory observation, in-depth interviews, and documentation for the same data source simultaneously. The data obtained were analyzed using Miles \& Huberman's theory which included data reduction, data display and conclusions.

\section{Result and Discussion}

The research data were obtained through the process of interviewing, observing and documenting. The presentation of the data used in this study is the presentation of qualitative data.

\subsection{Local Wisdom Values Developed by the Schools}

There are several local wisdom values were developed by the school. This is hinted by the principal of PAUD Bunda Maria Grazia's statement, which stated "what we have developed right now is about traditional clothing, regional food, traditional houses which are explained in a simple way while we didn't teach them the Manggaraian folksongs because it was difficult for us to teach". In line with that statement, the teacher at PAUD Bunda Maraia Grazia also explained that "in the learning process we taught the children in the simple explanation about cultural values so that children have a picture about the Manggaraian culture". For example, the traditional clothing that is often used, namely "towe songke Manggarai".

When the lesson took place with the dance sub-theme, it was found that the teacher mentioned the examples of Manggarai regional dances such as the caci dance. Then the teacher explains and shows the traditional equipment or clothes used by the caci dance participants simultaneously, as well as the songs during caci dance. In addition, the teacher also narrated them about the Manggarai traditional house, namely the mbaru gendang." 
The document of the weekly learning implementation plan and the daily lesson plan made by the teacher showed that the teacher writes this down in the learning tools, for example in the development of themes, weekly learning implementation plan and the daily lesson plan utilized by the teachers. Based on the data above-mentioned, it can be concluded that the certain school develops a curriculum based on local wisdom both in its planning which appears in the learning tools in the form of theme development, preparation of weekly learning implementation plans and daily learning implementation plans as well as in the implementation of learning.

\subsection{Local Wisdom Based Curriculum Development Model at PAUD Maria Grazia Ruteng}

Manggarai local wisdom-based curriculum development at PAUD Maria Grazia Ruteng appears in the development of planning and in the learning implementation as well.

\section{Planning Development}

Planning development starts from developing a theme into a learning sub-theme. Learning themes in the PAUD Maria Grazia were developed into several learning sub-themes that have local content values. Based on the existing data, it was found that the themes developed were arts, culture and sports. From this theme, it is then developed into several sub-themes, namely painting and drawing, dance, music, drama and performing arts. Based on this theme, the teacher started to explain to the children about the traditional clothing used by Caci dancers when performing regional traditional dances and mentioned the Manggarai regional dance. While the traditional house is explained when they learn about the sub-theme of painting and pictures and for the music sub-theme, the teacher explains everything about the songs and folk songs.

Based on the existing data, the teacher develops the theme of cultural arts and sports into sub-themes of dance, music, painting and drawing, acting and performance. This indicates that the school and its teachers have developed a curriculum on planning development that includes developing themes on arts, culture and sports into several sub-themes, namely (1) dance with its sub-sub-theme, the "caci" dance. (2) Music with its sub-sub-themes, namely the Manggaraian song "Embong" and (3) Painting with its sub-sub-theme, namely "Mbaru Gendang".

\section{The Development of Learning Implementation}

The curriculum development related to the development of learning implementation appears in two types of development, namely the development of teaching materials and the development of learning media.

\subsection{Teaching Material Development}

Before carrying out teaching and learning, teachers at PAUD Bunda Maria Grazia developed learning materials based on learning themes and sub-themes. This can be observed in the daily learning implementation plan made by the teachers. Teaching materials were developed based on the sub-themes that have been composed. Teaching materials were written directly in the daily learning implementation plan and they were not made separately. For instance, the dance sub-theme, then the material should be about the Manggaraian regional dance, namely the Caci dance and the Ndundundake dance. The music sub-theme is about Manggarai folk songs. For example, the song "Embong", while the sub-theme of painting, the material should be drawing and coloring Mbaru Gendang.

Therefore, based on the data, it can be concluded that the PAUD teachers of Bunda Maria Grazia had developed their teaching material based on the sub-themes that have been well 
developed. On the other side, the material taught is about Manggarai local culture which includes regional dances, folk songs and traditional Manggarai regional houses.

\subsection{Teaching Media Development}

Learning media is something that cannot be separated from the learning process. The use of media in teaching and learning will facilitate the learning process so that what is conveyed would be truly understood by students. The media developed by the PAUD Bunda Maria Grazia is composed in accordance with the local culture of the Manggarai area. Among them are posters or photos of people wearing traditional Manggarai clothing. In addition, during learning processes, children perform dance using traditional Manggaraian clothing on the year-end performances at school.

Learning media that are developed and applied during learning and teaching are adjusted into themes and sub-themes. Apart from using photos/posters/pictures, the children also wore traditional Manggarai clothing and trained to draw mbaru gendang picture and then color them. They were also trained to fold the shape of a house/mbaru gendang from origami paper. Learning activities based on the culture and local wisdom of Manggarai were documented well by the school in the form of photos display of learning activities.

Based on the available data, it can be assumed that PAUD Bunda Maria Grazia has developed a local wisdom-based learning media based on the sub-sub themes that have been composed. Therefore, there is a correspondence between the sub-themes developed with the material and the media used in learning. Murray Print (1993) in Haenilah (2016: 20) describes the three roles of teachers. One of them is acting as a developer/creator. As a developer, this role includes the duties of the teacher which is related with the design the curriculum/ planning developer, implementing or developing teaching-learning and evaluating the learning. PAUD teachers on that case also showing the same role.

First, planning developers. There are five roles for PAUD teachers as planning developers. Among them, are (1) teachers must be able to develop the level of developmental achievement from all aspects of development into a number of indicators of developmental achievement. (2) The teacher must learn a theme that can serve as an umbrella for a number of indicators of developmental achievement in accordance with the child's environmental conditions. (3) Teachers must be careful in identifying games that could challenge early childhood development. (4) The teacher must design an evaluation that refers to the development of the child's potential (and not on the competency achievement). (5) The teacher must be able to package points 1 and 4 into the lesson plan for the annual, term, weekly and daily programs. The teacher at PAUD Bunda Maria Grazia in glimpse has carried out their role as the planning developers, seen in the learning tools made and the development of themes, sub-themes and sub-subthemes in the learning.

Second, learning developer. The role of the teacher as a learning developer includes: (1) the teacher must be able to choose games that are attractive to children. (2) The teacher must try to make games as the only learning tool. (3) The teacher must make the stages of scientific approach as the procedure for children's play. (4) Teachers must make every effort so that when children play, all children can facilitate their development. (5) Teachers must make effort so that all children are interested in learning. (6) Teachers must make tries so that children avoid feeling bored.

In relation to the role of teachers as the learning developers, PAUD teachers of Bunda Maria Grazia show their role in implementing local wisdom-based learning. The teachers adjust 
the material and media used in learning based on the themes, sub-themes and sub-subthemes being developed.

Local culture-based learning for early childhood education according to Sugiyanti (2012: 8 ) is a learning program that provides educational stimulation to assist children's physical and spiritual growth and development by emphasizing understanding and appreciation of the way of life, customs, habits, traditions, arts, thoughts, system of value, a specific way of working belong to the community or ethnic group.

Learning development based on local culture is based on the concept of DAP (Developmentally Appropriate Practice) which states that learning for early childhood should be in accordance with the social and cultural environment in which the child lives. In addition, it is also should base on local culture that has not been maximizing optimally or even abandoned slowly so that children in their learning process need to be introduced to the cultural values and make them understand on their cultural environment. This is in line with Widiastuti's opinion (20120) that the introduction of culture in early childhood education is intended so facilitate children's learning in accordance with the existing environment, besides of that it is to equip children's lives in the future. It is further explained that learning is applied in themes, subthemes, materials or activities, educative play tools or media and refers to the cultural environment around the child.

Research by Munawar, et al (2013) states that to prepare learning based on local cultural wisdom, the theme chosen to be developed in PAUD's learning must be adjusted to the conditions of each area. This is because in early childhood education, themes function to unify curriculum content in a holistic plan, enrich students' vocabulary, make learning more meaningful and help children recognize various concepts easily and clearly. So, the theme is the actualization of the concept of children's interest which is the focus of planning or the starting point of planning in the learning process.

The integration of local culture in learning is very beneficial for the meaning of the learning process and learning outcomes because students get contextual learning experiences and perceptual materials to understand the concept of science in their local (ethnic) culture.

\section{Conclusion}

PAUD Bunda Maria Grazia is one of the early childhood education institutions that has a great concern for cultural preservation. Proofs were indicated by the development of cultural values in the school learning process. The curriculum development model looks at the development of planning and learning development. In planning development process, the institution develops themes and sub-themes that contain cultural elements and in the development of learning, the teacher selects interesting materials and appropriate media according to the themes and sub-themes that have been developed

\section{References}

[1] Arikunto, S. 2010. Prosedur Penelitian Suatu Pendekatan Praktik. Jakarta: Rineka Cipta.

[2] Haenilah, Y. Een. 2015. Kurikulum dan Pembelajaran PAUD. Yogyakarta: Media Akademi.

[3] Idi, Abdulah. 2014. Pengembangan Kurikulum Teori dan Praktik. Jakarta: PT Rajagrafindo Persada.

[4] Masnipal. 2013. Siap menjadi Guru dan Pengelola PAUD Profesional. Jakarta: PT Gramedia. 
[5] Munawar, Muniroh, dkk. 2013. Pengembangan Model PembelajaranInovatif melalui Pendekatan in House Training Berbasis Kearifan Budaya Lokal. Jurnal Penelitian PAUDIA. 2/1:1-13.

[6] Peraturan Menteri Pendidikan dan Kebudayaan No 137 Tahun 2014 tentang Standar PAUD.

[7] Siahaan, Nurhalimah. 2018. Model Pembelajaran Berbasis Kearifan Lokal. Prosiding Seminar Nasional Fakultas Ilmu Sosial Universitas Negeri Medan Vol 2. 649-651.

[8] Siwi, Widiastuti. 2012. Pengembangan Pembelajaran Berbasis Budaya Lokal. Jurnal Pendidikan Anak. Vol 1/Edisi 1.

[9] Sugiyono. 2012. Metode Penelitian Pendidikan: Pendekatan Kualtitatif, Kualitatif dan R\& D. Bandung: Alfabeta.

[10] Yusuf Warni \& Abdul Rahmat. 2020. Model Pengembangan Pembelajaran Anak Usia Dini Berbasis Budaya Lokal Di TK Negeri Pembina Telaga Kabaupaten Gorontalo. Prosiding Webinar Magister Pendidikan Nonformal Universitas Negeri Gorontalo.61-70. 